\title{
AN EXPERIMENTAL DESIGN IN THE OPTIMIZATION OF VARIOUS TABLET EXCIPIENT FORMULATIONS = A CONCISE REVIEW
}

\author{
IYAN SOPYAN ${ }^{1,3}$, RETNO WAHYUNINGRUM ${ }^{2}$, INSAN SUNAN K. S. ${ }^{1}$
}

1Department of Pharmaceutical and Technology of Pharmacy, Faculty of Pharmacy, Universitas Padjadjaran, Bandung, Indonesia, ${ }^{2}$ Department of Pharmacy, Faculty of Science and Technology, Universitas Sembilanbelas November, Kolaka, Indonesia, ${ }^{3}$ Study Center of Dosage Form Development, Faculty of Pharmacy, Universitas Padjadjaran, Bandung, Indonesia

Email: i.sopyan@unpad.ac.id

Received: 14 Oct 2021, Revised and Accepted: 24 Nov 2021

\begin{abstract}
The use of an experimental design technique in the development of various pharmaceutical preparations, including tablet preparations, has become the latest trend. Because of their ease of use, tablet formulations are popular among both producers and patients. To increase the usage of tablets in diverse circles and settings, researchers are working to develop a variety of tablet excipients for various functions. Fast dissolving tablets (FDT), effervescent tablets, modified-release tablets, oral mucoadhesive tablets, gastroretentive tablets, and colon targeted tablets are some of the tablet formats that have been developed in addition to traditional tablets. This review will look at how formulation optimization in tablet preparations has been done during the previous ten years using specific literacies. The articles for this review were found using the keywords tablet, excipient, matrices, formulation, and QBD in specialized databases such as Elsevier, Pubmed, and Cambridge. Other options include Springer publications, material from the Internet, and articles published online by The Lancet Respiratory Medicine, Medscape, and Statpearls. The formulation design strategy is based on the experimental design approach carried out on the kind of tablet preparation, which has distinct important quality parameters.
\end{abstract}

Keywords: Tablet, Excipient, Matrics, Formulation, QBD

(C) 2022 The Authors. Published by Innovare Academic Sciences Pvt Ltd. This is an open access article under the CC BY license (https://creativecommons.org/licenses/by/4.0/) DOI: https://dx.doi.org/10.22159/ijap.2022v14i1.43380. Journal homepage: https://innovareacademics.in/journals/index.php/ijap

\section{INTRODUCTION}

Quality by design (QBD) is a concept of a systematic approach in product development that begins with defining targets and emphasizing product understanding and process control, based on scientific justification and quality risk management. In this concept, the factors that affect the quality of a product are identified early on and optimized simultaneously, systematically, and quickly using a technique called the design of experiment (DoE). This technique was later adopted into the pharmaceutical manufacturing process and termed formulation by design (FbD) [1].

Tablet preparations have very good reception. The ease of handling from the producer and patient side is the advantage of tablet preparations [2]. Therefore, many researchers are developing tablets with various matrices that have their intended use according to the need for safer and more effective therapy. This review summarizes various additives in tableting. It's has been developed according to the type of tablet and the experimental design approach that has been used for development. Ordinarily, additives in different tablet types require properties to support the desired tablet profile. It is necessary to identify critical points in the relevant tablet evaluation. Reviewing the additives in various tablets will be useful information for formulators in preparing the tablet design.

\section{Optimization of various tablet excipients}

\section{Conventional tablets}

Excipients are utilized in traditional tablets to keep BAF in a compressible mass that can be crushed to release Drug Material into body fluids. As a result, the tablet has earned the moniker of "basic tablet" [3]. The regular tablet is most widely used for rapid-release tablets [3-6]. In addition to their use in medicine, conventional tablets have been produced for herbal preparations, nutraceuticals, and even probiotic bacteria [7-9]. In recent medication development trends, customized drug materials such as nanosuspension, liquid-solid, and solid dispersion drug materials are replacing regular tablets [10-12].

Excipients in traditional tablets are used to contain drug in a compressible mass that can be crushed to release BAF from the excipient into body fluids. As a result, the tablet is known as a simple tablet [3]. For instant release tablets, the standard tablet is most commonly utilized [3-6]. Conventional tablets have been designed for herbal preparations, nutraceuticals, and even probiotic microorganisms in addition to their application in medicine [7-9]. In recent medication development trends, customized BAFs such as nanosuspension, liquid-solid, and solid dispersion drug are replacing regular tablets [10-12]. The survival of bacteria in the excipient, which is referred to as viability in the probiotic tablet, is also regarded as a significant element in formulation optimization [8].

The formulation factors used as independent variables in the optimization of a conventional tablet include fillers, binders, disintegrants, glidants, and lubricants [5, 7]. In addition to formulation factors, process parameters are also involved in the development of conventional tablet preparations, which include the speed and duration of a mixing [7].

Several experimental designs that have been used for the development of conventional tablets include a variety of factorial designs [6, 9], central composite design [8, 11, 15], Box-Behnken design $[4,16,17]$, simplex lattice design [7], simplex centroid design [13], optimal mixture design [18].

\section{Fast disintegrating tablet (FDT)}

FDT is a preparation with excipients capable of disintegrating in a liquid atmosphere in less than 1 minute. There are two ways to use FDT: dissolved in water and then drunk, and put in the mouth until the excipient disintegrates in the mouth. Tablets with a second use are referred to as orodispersible tablets (ODT). The purpose of FDT is to increase bioavailability in the pre-gastric area, increase the therapeutic effect, and increase drug adherence and acceptance in geriatric and pediatric patients [19-21].

Several quality characteristics in FDT tablets are of particular relevance, in addition to the physical quality parameters that apply to all tablets. Disintegration time with criteria that were faster than normal tablets, tablet wetting time, water absorption ratio, drug release, and flavor were the factors that were focused on while developing FDT excipients $[22,23]$. The intended quality metrics, as well as the qualities of additives that affected these parameters, such as disintegrants and sweeteners, might be studied. The disintegrant material employed in FDT might be either a mixture or a super disintegrant [24]. 


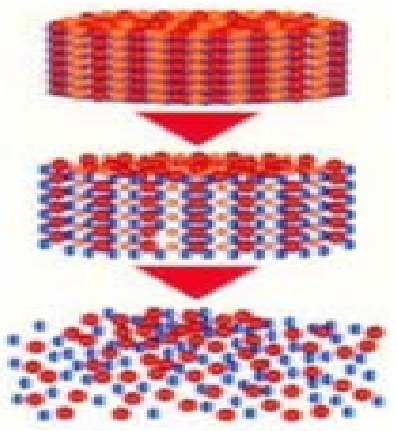

Fig. 1: Basic concept of FDT [19]

Experimental designs that have been used for the development of FDT excipients include factorial designs [22, 23, 25], central composite design $[1,26]$, Box-Behnken design [27, 28], simplex lattice design $[19,20]$, simplex centroid design [29].

Effervescent tablets are tablet preparations that release $\mathrm{CO}_{2}$ when $\mathrm{NaHCO}_{3}$ reacts with organic acids, allowing them to disintegrate and disperse quickly in water. This medication was created for individuals who have trouble swallowing tablets, such as the elderly and children, as well as those who have dysphagia. Preparation was also produced to improve the therapeutic impact $[30,31]$.

Effervescent preparations, in addition to having physical quality parameters such as tablets in general, must also have a taste that is acceptable to the patient. In addition, foaming time, $\mathrm{CO} 2$ content, and $\mathrm{pH}$ are also important parameters in the development of effervescent preparations. Thus, formulation attributes that are important to maintaining these quality parameters are sweeteners and the combination of $\mathrm{NaHCO}_{3}$ and organic acids [31]. The experimental design approach to the development of effervescent preparations is still limited. Studies that have been reported have demonstrated the use of factorial and central composite designs [30-32].

\section{Tablet oral mucoadhesive}

Bioadhesives, or surfaces that can link to a biological surface, such as the mucosa around the mouth, are produced by excipients in mucoadhesive oral tablets, allowing the preparation to stick in the mouth. The two varieties of this preparation are buccal tablets, which are connected to the mucosa of the cheek area, and sublingual tablets, which are attached to the area under the tongue. The medicine is released into the mouth for rapid absorption through the permeable blood vessels surrounding the oral mucosa, avoiding gastric acid destruction and first-pass effects in the liver. The most prevalent medications produced in this procedure are peptide drugs. Usually, the drugs made in this preparation are peptide drugs. In addition, this preparation can be intended also to provide a local effect on the mouth $[33,34]$.
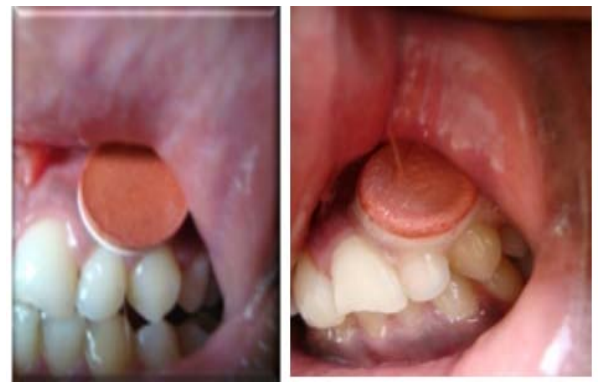

Fig. 2: Mucodhesif oral tablet [33]

The ability of the medicine to diffuse from the preparation and the adhesive strength of the bioadhesive are two critical elements in this preparation. This is related to the drug's requirement for oral mucosal survival and release. As a result, the polymer that aids in the adhesion of this preparation is an important formulation feature to consider. The most often used polymers are hydrophilic [35]. The use of an experimental design technique to produce this preparation is still limited. The usage of factorial and simplex lattice designs has been documented in studies [33-38].

\section{Gastroretentive tablet}

Gastroretentive tablets can persist in the stomach. It was intended to increase the bioavailability of the drug in the stomach or maintain a local therapeutic effect on the stomach. There are several types of gastroretentive excipients: excipients that float in gastric fluid with low foaming or density mechanism, bioadhesive excipients, excipients that expand in gastric fluidal, and excipients that sink in gastric fluidal with a high-density mechanism. Several preparations with excipient combinations have also been developed [16, 27, 39-44].

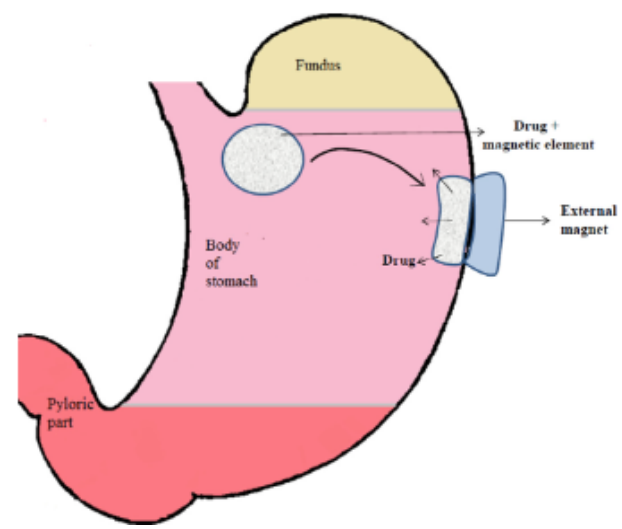

Fig. 2: Gastroretentive tablet [44]

An important quality parameter in gastro retentive preparations is their ability to persist in the stomach according to the kind of excipient and their respective mechanisms, which are usually tested in vitro or in vivo. In floating excipients, the formulation attribute is an effervescent material or material and process providing a low density. In the bioadhesive excipient, the formulation attribute is an adhesive-forming polymer on the gastric mucosa. In expanding excipients, the attribute of the formulation is that the polymer forms an expanding mass in gastric fluid. In high-density excipients, the formulation attribute is high-density excipients $[16,27,39,41,45]$.

Experimental designs that have been used for the development of gastroretentive preparations include factorial design, composite design, Box-Behnken design, simple lattice design, and simplex centroid design [16, 27, 46-48].

\section{Modified release tablet}

Excipients in modified-release tablets have the ability to hold the drug in such a way that its release can be controlled. This preparation is intended to increase the duration of action of the drug and reduce toxicity. Several excipients have been developed: hydrophilic excipients and osmotic pore excipients [48-50].

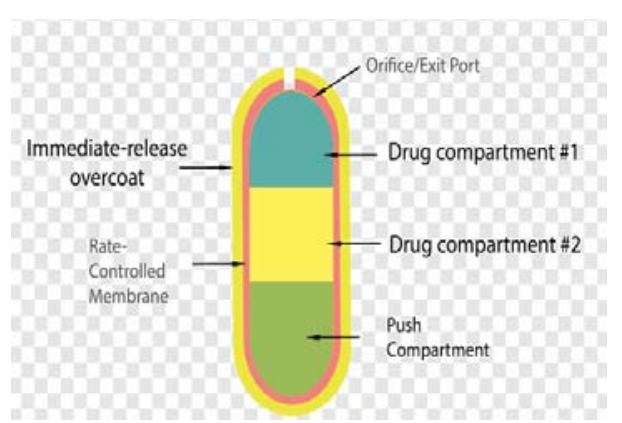

Fig. 4: Modified release tablet system [48] 
Table 1: Matrices and experimntal design for floating tablets

\begin{tabular}{|c|c|c|c|}
\hline No. & Matrices & Experimental design & Refferences \\
\hline 1 & Sodium alginat, pectin and sodium bicarbonate & Box-Behnken & Hanif et al., 2017, [16] \\
\hline 2 & $\begin{array}{l}\text { Hydroxypropyl methylcellulose (HPMC) K15M carboxymethyl } \\
\text { tamarind gum (CMTG) }\end{array}$ & Composite design & Mali et al. 2017, [27] \\
\hline 3 & HPMC K15M (X1), kappa-Carrageenan (X2) and sodium bicarbonate & Simple lattice design & Kamare et al. m, 2021, [46] \\
\hline 4 & $\begin{array}{l}\text { Hydroxy Propyl Methyl Cellulose K4M, ethyl cellulose (4cps) and } \\
\text { sodiumbicarbonate }\end{array}$ & Full actorial design & Maddiboyina et al. 2020, [47] \\
\hline 5 & ethocel K100LV, Methocel K15M and Carbopol 934 & Simplex centroid design & Raza et al., 2017, [48] \\
\hline
\end{tabular}

The drug release profile is the typical quality parameter of this preparation because the objective of this excipient is to modify drug release. As a result, the elements that operate to contain the medication material are the formulation features that need to be adjusted. The formulation attribute for hydrophilic excipients is hydrophilic polymeric polymers. The formulation attribute for osmotic pore excipients is in situ pore-forming polymeric polymers [51-53]. The factorial design, central composite design, BoxBehnken design, and simplex centroid design have all been used in the creation of modified loose dosage forms [54-58].

\section{Colon targeted tablets}

Tablets that are colon-targeted do not break down in the digestive tract until they reach the small intestine. This formulation was designed to have a local therapeutic impact, similar to how antibiotics are used to treat infections of the large intestine. These formulations can be used to boost protein and peptide drug absorption $[59,60]$.

The ability of the dosage form to endure degradation in the gastrointestinal tract, the drug release profile in the large intestine, and the percentage of drug entrapment are all quality characteristics to consider in this preparation. Coating materials and hydrophilic polymer excipients are two formulation properties that must be maintained [61, 62]. The experimental designs that have been used, such as design factorial and central composite design $[61,62]$, are still limited.

\section{CONCLUSION}

The experimental design approach has become a new trend in the development of various tablet excipients. The various experimental designs, the factorial design is the most chosen because of its flexibility. In general, the development of effervescent, oral mucoadhesive, and colon targeted excipients, research with an experimental design approach is still limited to a small number of experiment design variations.

\section{FUNDING}

Nil

\section{AUTHORS CONTRIBUTIONS}

All authors have contributed equally.

\section{CONFLICT OF INTERESTS}

Declared none

\section{REFERENCES}

1. Singh S, Prajapati K, Pathak AK, Mishra A. Formulation and evaluation of floating tablet of captopril. Int J PharmTech Res. 2011;3:333-41.

2. Natoli D, Levin M, Tsygan L, Liu L. Development, optimization, and scale-up of process parameters: tablet compression. In: Developing solid oral dosage forms. Elsevier; 2017. p. 917-51.

3. Pratiwi PD, Nugroho AK, Lukitaningsih E. Optimasi tablet lepas cepat levofloksasin hidroklorida menggunakan crospovidone sebagai disintegran dan studi disolusi efisiensi. Majalah $\begin{array}{ll}\text { Farmaseutik. 2020;16(1):58-63. } & .\end{array}$

doi: 10.22146/farmaseutik.v16i1.48352.

4. Akhtar MF, Hanif M, Majeed A, Shah S. Formulation development and optimization of captopril containing tablets through Box-Behnken design. Lat Am J Pharm. 2018;37:141423.
5. Alpizar Ramos S, Gonzalez-de la Parra M. Application of the sequential design of experiments to develop ibuprofen (400 $\mathrm{mg}$ ) tablets by direct compression. Asian J Chem Pharm Sci. 2017;2:10-5.

6. Bajwa PS, Sharma J, Bhargava A, Sharma S, Sharma AR, Raina BR. Design and development of immediate-release tablets of terbutaline sulfate using 32 full factorial statistical design. APJHS. 2018;5(1):47-52. doi: 10.21276/apjhs.2018.5.1.11.

7. Damayanti D, Sari IP, Sulaiman TNS, Bestari AN, Setiawan IM. The formulation of pacing (Costus speciosus) extracts tablet by using Avicel®Ph 200 as filler-binder and amylum as disintegration agent. Indonesian J Pharm. 2018;29(1). doi: 10.14499/indonesianjpharm29iss1pp29.

8. Huq T, Vu KD, Riedl B, Bouchard J, Han J, Lacroix M. Development of probiotic tablet using alginate, pectin, and cellulose nanocrystals as excipients. Cellulose. 2016;23(3):1967-78. doi: 10.1007/s10570-016-0905-2.

9. Hadisoewignyo L, Soegianto L, Ervina M, Wijaya I, Santoso SD, Tania N. Formulation development and optimization of tablet containing a combination of Salam (Syzygium Polyanthum) and Sambiloto (Andrographis paniculata) ethanolic extracts. Int J Pharm Pharm Sci. 2016;8:267-73.

10. Prapajati DB, Rao MS, Barot MT. Development, optimization and evaluation of liquisolid compact tablet of aripiprazole by using factorial design. Int J Pharmacol Res. 2020;12.

11. Tong Y, Zhang P, Dang L, Wei H. Monitoring of cocrystallization of ethenzamide-saccharin: insight into the kinetic process by in situ Raman spectroscopy. Chem Eng Res Des. 2016;109:249-57. doi: 10.1016/j.cherd.2016.01.032.

12. Dhaval M, Jalpa M, Ramesh P, Kalpesh P, Jayant C. Formulation, evaluation and optimization of the felodipine nanosuspension to be used for direct compression to tablet for in vitro dissolution enhancement. Pak J Pharm Sci. 2016;29:1927-36.

13. Ainurofiq A, Choiri S. The interaction of a binary/ternary interactive mixture of hydrophobic-hydrophilic materials on the drug distribution and drug release performance in the tablet formulation. IOP Conf Ser: Mater Sci Eng. 2017;176. doi: 10.1088/1757-899X/176/1/012006.

14. Asif M, Yasir M, Bhattacharya A, Bajpai M. Formulation and evaluation of gastroretentive dosage form for fluvastatin sodium. Pharm Glob Int J Comp Pharm. 2010;1:1-4.

15. Bushra R, Shoaib MH, Ali H, Zafar F, Naeem MI, Aslam N. Formulation design and optimization of aceclofenac tablets (100 mg) using central composite design with response surface methodology. Latin American Journal of Pharmacy. 2014;33:1009-18.

16. Hanif M, Abbas G. pH-responsive alginate-pectin polymeric rafts and their characterization. Adv Polym Technol. 2018;37(5):1496-506. doi: 10.1002/adv.21808.

17. Kushare SS, Gattani SG. Design and development of a microwave generated lactose monohydrate-microcrystalline cellulose-based multifunctional excipient composites for tablet formulation using box-Behnken design. J Drug Deliv Ther. 2019;9:1-17.

18. Oh DJ, Lee BC, Hwang SJ. Solubility of simvastatin and lovastatin in mixtures of dichloromethane and supercritical carbon dioxide. J Chem Eng Data. 2007;52(4):1273-9. doi: 10.1021/je700019h.

19. Farahiyah D, Sulaiman TNS. Pengaruh kombinasi superdisintegrant crospovidone dan croscarmellose sodium pada sifat fisik dan disolusi fast disintegrating tablet hidroklorotiazid. Maj Farm. 2020;17:140-7. 
20. Lestari ABS, Fudholi A, Nugroho AK, Setyowati EP. Formula optimization of fast disintegrating tablet (FDT) of Centella asiatica (L.) Urb. ethanolic Extract. J Ilmu Kefarmasian Indones. 2018;16:94-9.

21. Wulandari RS, Fudoli A, Herowati R. Optimasi formula Fdt natrium diklofenak dengan kombinasi Ssuperdisintegrant primojel@, primellose $\AA$ dan komponen effervescent dengan metode simplex lattice design. Chmk Pharmaceutical Scientific Journal 2019;2:39-47.

22. Dave V, Yadav RB, Ahuja R, Yadav S. Formulation design and optimization of novel fast dissolving tablet of chlorpheniramine maleate by using lyophilization techniques. Bull Fac Pharm Cairo Univ. 2017;55(1):31-9. doi: 10.1016/j.bfopcu.2016.12.001.

23. Kumar RK, Diskin Posner I, Goldberg I. Solid-state supramolecular chemistry of porphyrins. Ligand-bridged tetraphenylmetalloporphyrin dimers. J Inclus Phenom Macrocyclic Chem. 2000;37(1):219-30. doi: 10.1023/A:1008118119529

24. Tafere C, Yilma Z, Abrha S, Yehualaw A. Formulation, in vitro characterization and optimization of taste-masked orally disintegrating co-trimoxazole tablet by direct compression. PLOS ONE. 2021;16(3):e0246648. doi: 10.1371/ journal.pone.0246648, PMID 33725014.

25. Sarfaraz M, Dhruv RK, Doddayya H, KAA K. Factorial design based optimization of hydroxyzine hydrochloridef dissolving tablets. Indian J Pharm Sci. 2020;82:797-808.

26. Maroof K, Zafar F, Ali H, Shah SN, Bushira R, Naveed S. Development and optimization of fast dispersible flurbiprofen $100 \mathrm{mg}$ tablets by central composite design. Lat Am J Pharm. 2016;35:685-94.

27. Mali KK. Design and optimization of modified tamarind gumbased floating-bioadhesive tablets of verapamil hydrochloride. Asian J Pharm. 2016;10(4):239-50. Doi: 10.22377/ ajp.v10i04.862

28. Okhuelegbe ES, Osayande EP, Amara IM. Optimization of disintegrant blends using box behnken design in the formulation of fast disintegrating tablets of diclofenac sodium. Niger J Pharm Appl Sci Res. 2017;6:1-7.

29. Kadry H. Formulation and optimazation of verdenavil hydrochloride oral disintegrating tablet: effect of superdisntegran. Al-Azhar J Pharm Sci. 2016;53:39-57.

30. Mohamed S, Tocher DA, Price SL. Computational prediction of salt and cocrystal structures-does a proton position matter? Int J Pharm. 2011;418(2):187-98. doi: 10.1016/j.ijpharm.2011.03.063, PMID 21497185.

31. Taymouri S, Mostafavi A, Javanmardi M. Formulation and optimization of effervescent tablet containing bismuth subcitrate. J Rep Pharma Sci. 2019;8(2):236. doi: 10.4103/jrptps.JRPTPS_11_19.

32. Mahapatra APK, Saraswat R, Botre M, Paul B, Prasad N. Application of response surface methodology (RSM) in statistical optimization and pharmaceutical characterization of a patient compliance effervescent tablet formulation of antiepileptic drug levetiracetam. Future J Pharm Sci. 2020;6:1-14.

33. Manwar J, Kumbhar DD, Bakal R, Baviskar S, Manmode R. Response surface based co-optimization of release kinetics and mucoadhesive strength for an oral mucoadhesive tablet of cefixime trihydrate. Bull Fac Pharm Cairo Univ. 2016;54(2):227-35. doi: 10.1016/j.bfopcu.2016.06.004.

34. Sahoo A, Kumar NSK, Suryanarayanan R. Crosslinking: an avenue to develop stable amorphous solid dispersion with high drug loading and tailored physical stability. J Control Release. 2019;311-312:212-24. doi: 10.1016/j.jconrel.2019.09.007, PMID 31499085.

35. Esim O, Savaser A, Ozkan CK, Bayrak Z, Tas C, Ozkan Y. Effect of polymer type on characteristics of buccal tablets using factorial design. Saudi Pharm J. 2018;26(1):53-63. doi: 10.1016/j.jsps.2017.10.013, PMID 29379333.

36. Mandal D, Ojha PK, Nandy BC, Ghosh LK. Effect of carriers on solid dispersions of simvastatin (Sim): physicochemical characterizations and dissolution studies. Pharm Lett. 2010;2:47-56.

37. Ramani V, Sailor GU, Patel MM, Parmar GR, Seth AK. Experimental design approach for the formulation of controlled release buccal bilayer tablets of carvedilol. J Integr Health Sci. 2018;6:54.

38. Raval J, Yagnik A. Formulation and evaluation of buccoadhesive tablets of buspirone hidrochloride. Highlights Med Sci. 2021;4:128-46

39. Meka L, Kesavan B, Chinnala KM, Vobalaboina V, Yamsani MR Preparation of a matrix type multiple-unit gastro retentive floating drug delivery system for captopril based on gas formation technique: in vitro evaluation. AAPS PharmSciTech. 2008;9(2):6129. doi: 10.1208/s12249-008-9090-4, PMID 18459051.

40. Patel D, Sawant KK. Self micro-emulsifying drug delivery system: formulation development and biopharmaceutical evaluation of lipophilic drugs. Curr Drug Deliv. 2009;6(4):41924. doi: 10.2174/156720109789000519, PMID 19534704.

41. Saha T, Ahmed N, Hasan I, Reza MS. Preparation, characterization and optimization of mucoadhesive domperidone tablets by box Behnken design. Dhaka Univ J Pharm Sci. 2020;19(1):65-76. doi: 10.3329/dujps.v19i1.47820.

42. Sugimoto T, Yamazaki N, Hayashi T, Yuba E, Harada A, Kotaka A, Shinde C, Kumei T, Sumida Y, Fukushima M, Munekata Y, Maruyama K, Kono K. Preparation of dual-stimuli-responsive liposomes using methacrylate-based copolymers with $\mathrm{pH}$ and temperature sensitivities for precisely controlled release. Colloids Surf B Biointerfaces. 2017;155:449-58. doi: 10.1016/j.colsurfb.2017.04.043, PMID 28463812.

43. Dehghani F, Farhadian N, Golmohammadzadeh S, Biriaee A, Ebrahimi M, Karimi M. Preparation, characterization and in vivo evaluation of microemulsions containing tamoxifen citrate anticancer drug. Eur J Pharm Sci. 2017;96:479-89. doi: 10.1016/j.ejps.2016.09.033, PMID 27693298.

44. Sopyan I, Sriwidodo WR, Wahyuningrum R, P NA. A review: floating drug delivery system as a tool to improve dissolution rate in gastric. Int J Appl Pharm. 2020;7:51-4. doi: 10.22159/ijap.2020v12i4.38415.

45. Aleti R, Baratam SR, Jagirapu B, Kudamala S. Formualtion and evaluation of metformin hydrochloride and gliclazide susteined release bilayer tablet: a combination theraphy in management of diabetes. Int J Appl Pharm. 2021;13:343-50.

46. Mali S, Oza N. Centeral composite design for formulation and optimization of longacting injectable (LAI) mikrospere of paliperidone. Int J Appl Pharm. 2021;13(5):87-98. doi: 10.22159/ijap.2021v13i5.42297

47. Patel MB, Shaikh F, Patel V, Surti NI. Application of simplex centroid design in formulation and optimization of floating matrix tablets of metformin. Int J Appl Pharm Sci. 2017;7:23-30.

48. Kamere K, Gopalakrishna SV, Subbareddy GV. Formulation and optimization of gastroretentive glimepiride floating matrix tablet. Int J Life Sci Pharm Res. 2021;11:136-47.

49. Maddiboyina B, Hanumanaik M, Nakkala RK, Jhawat V, Rawat $P$, Alam A, Foudah AI, Alrobaian MM, Shukla R, Singh S, Kesharwani P. Formulation and evaluation of gastro-retentive floating bilayer tablet for the treatment of hypertension. Heliyon. 2020;6(11):e05459. doi: 10.1016/j.heliyon. 2020.e05459, PMID 33241144.

50. Raza A, Bukhari NI, Karim S, Hafiz MA, Hayat U. Floating tablets of minocycline hydrochloride: formulation, in vitro evaluation and optimization. Future J Pharm Sci. 2017;3(2):131-9. doi: 10.1016/j.fjps.2017.05.001.

51. Moinuddin SM, Ruan S, Huang Y, Gao Q, Shi Q, Cai B, Cai T. Facile formation of co-amorphous atenolol and hydrochlorothiazide mixtures via cryogenic-milling: enhanced physical stability, dissolution and pharmacokinetic profile. Int J Pharm. 2017;532(1):393-400. 10.1016/j.ijpharm.2017.09.020, PMID 28893583.

52. Yang Y, Waring JF. Genomic approaches to drug-drug interactions. In: CEO APLPDP and, editor. Drug-drug interactions in pharmaceutical development [Internet]. John Wiley and Sons, Inc; 2007. p. 113-30.

53. Syed SM, Lahoti S, Syed AA. Controlled porosity osmotic tablet of atenolol: in vitro and in vivo evaluation. Marmara Pharm J. 2016;20(3):325-32. doi: 10.12991/mpj.20162040694.

54. Moin A, Roohi NKF, Rizvi SMD, Ashraf SA, Siddiqui AJ, Patel M, Ahmed SM, Gowda DV, Adnan M. Design and formulation of 
polymeric nanosponge tablets with enhanced solubility for combination therapy. RSC Adv. 2020;10(57):34869-84. doi: 10.1039/D0RA06611G.

55. Gunda RK, Manchineni PR. Statistical design and optimization of sustained-release formulations of pravastatin. Turk J Pharm Sci. 2020;17(2):221-7. doi: 10.4274/tjps.galenos.2019.70048, PMID 32454783.

56. Iffat W, Shoaib MH, Yousuf RI. Hydrophillic and hydrophobic polymer combination: formulation development and optimatization of nicorandil sustained release tablet. Lat Am J Pharm. 2017;36:907-17.

57. Kraisit P. Impact of hydroxypropyl methylcellulose (HPMC) type and concentration on the swelling and release properties of propranolol hydrochloride matrix tablets using a simplex centroid design. Int J App Pharm. 2019;11:143-51. doi: 10.22159/ijap.2019v11i2.31127.

58. Morovati A, Ghaffari A, Erfani Jabarian L, Mehramizi A. Single layer extended-release two-in-one guaifenesin matrix tablet: Formulation method, optimization, release kinetics evaluation and its comparison with mucinex® using box-behnken design Iran J Pharm Res. 2017;16(4):1349-69. PMID 29552045.

59. Parmar K, Patel J, Sheth N. Self nano-emulsifying drug delivery system for Embelin: Design, characterization and in vitro studies. Asian J Pharm Sci. 2015;10(5):396-404. doi: 10.1016/j.ajps.2015.04.006.

60. Bharti C, Nagaich U, Pandey J, Jain S, Jain N. Development of nitazoxanide-loaded colon-targeted formulation for parasitic intestinal infections: centre composite design-based optimization and characterization. Future J Pharm Sci. 2020;6:1-17.

61. Kotadiya RM, Savant NP, Upadhyay UM. Colon targeted Moringa gum compression coated tablets of capecitabine: A factorial approach. Pharmacophore. 2019;10(1).

62. Kim MS, Kim JS, Hwang SJ. Enhancement of wettability and dissolution properties of cilostazol using the supercritical antisolvent process: effect of various additives. Chem Pharm Bull (Tokyo). 2010;58(2):230-3. doi: 10.1248/cpb.58.230, PMID 20118585. 